\title{
The Role of Teachers in Digital-Based Thematic Learning at Elementary School
}

\author{
Windri Maryana ${ }^{1}$ \& Adolph Ian A. Dela Torre ${ }^{2}$ \\ ${ }^{1}$ Universitas Muhammadiyah Surakarta, Surakarta, Indonesia \\ ${ }^{2}$ Prenza National High School, Marilao, The Philipines \\ *Email \& Phone: windrimaryana98@gmail.com; +6285200329761
}

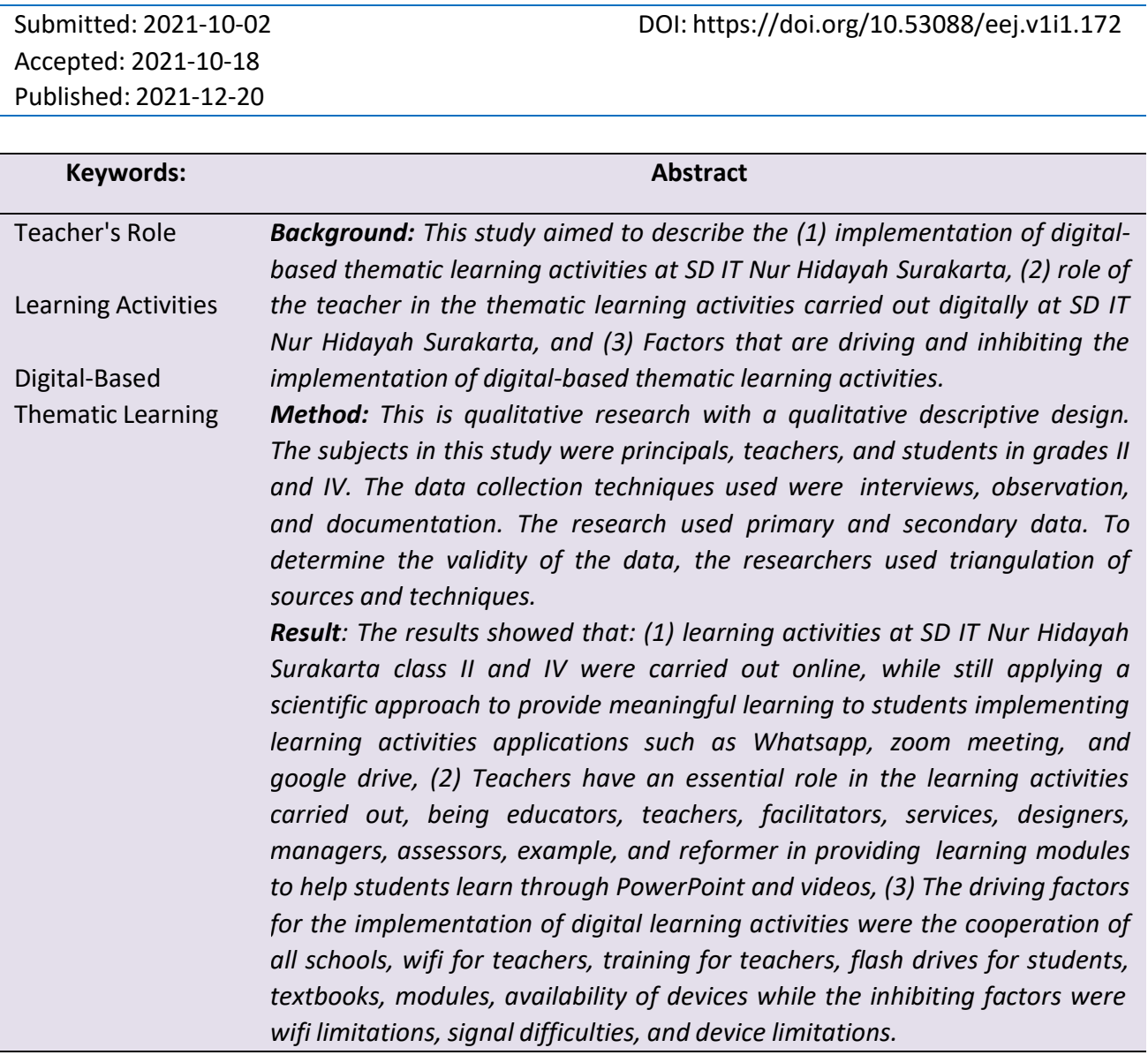

\section{INTRODUCTION}

Education is one of the essential elements in a country. It is one of the pillars of the progress of a country. The better the education in a country, the better the success in that country. The schools provide quality education to the people in Indonesia. In the implementation of education, some components are interrelated with each other. The components of the Education System are interrelated and integrated to achieve national

( ) 2021. This work is licensed under a CC BY-SA 4.0 
education goals (SISDIKNAS Law No. 20 of 2003). These components include a form of a learning environment, teachers, students, facilities, and infrastructure.

Teachers are one of the essential components in the implementation of education. Teachers in Javanese are known as "digugu." "Digugu" means that the students trust the knowledge conveyed by the teacher. Through imitation, the teacher is a role model for students in words, attitudes, manners, and behavior. The teacher has great authority and responsibility in guiding and fostering students (Hamid, 2017). Teachers can be described as professional educators who have the main task of teaching, educating, training, directing, guiding, assessing, and providing evaluations to students at the PAUD, SD, SMP, and SMA levels (Hamid, 2017).

Teachers play a role in interacting directly with students in learning activities. At the elementary school level, teachers carry out thematic learning activities using a scientific approach known as 5M (Observing, Questioning, Trying, Reasoning, and Communicating). The teacher's role is entirely in it to carry out all of these. Some of the teacher's roles include being an educator, a teacher, a facilitator, a service, a designer, a manager, and an assessor (Sadirman, 2011). The current rapid technological advances in education cannot shift the role of teachers in education. The teachers can use the advances in the existing technology to facilitate the learning activities to provide quality education to young generations. It can create a generation of active, creative, and fun learning activities (Utami, 2012).

Learning activities that have been previously done together in one room must now be separated from each other. Given the current state of Indonesia, it is not possible to carry out direct learning because of the Covid-19 virus. The government recommended carrying out online learning activities to continue carrying out learning activities. There needed adaptations or adjustments made by teachers and students to implement new learning. Teachers and students need knowledge and supporting facilities to succeed in online learning activities. Schools, teachers, students, and parents must migrate to a digital or online system in learning activities, UNESCO (2020); Jordan (2020); and Karp (2020). Current learning activities can take advantage of existing technological developments. Various applications can be used, such as WhatsApp, zoom, google classroom, email, google form, google meet, Edmodo, and Schoology. Enriquez (2014); Sicat \& Ed (2015) ; Iftakhar (2016); and So (2016).

Research on the role of teachers in learning activities in elementary schools has been conducted several times. Maryono (2017) examined the role of teachers in implementing thematic learning in elementary schools. At the same time, Zulaiha (2013) examined the role of elementary school teachers in learning in the era of digital technology. Rosyidah(2019) explored The Role of Classroom Teachers in Creating an Effective and Fun Learning Atmosphere to Increase Student Learning Motivation. Juwitawati(2019) investigated The Role of Teachers in Overcoming Students' Learning Difficulties in Class IV Thematic Learning, and Mursalin (2017) studied The Role of Teachers in the Implementation of Classroom Management in the Bungong Seulanga Cluster, Syiah Kuala District, Banda Aceh City. Arifudin (2015) investigated The Role of Teachers in the Character Education of Students in Grade V. While Kartika (2016) determined The Role of Teachers in Motivating Student Learning in Integrated Social Studies Subjects at SMP PGRI Ciledug. Fadlilah(2018) The Role of Teachers in Improving Student Motivation in Thematic Learning in Class IV SDI As-Salam Malang. Sumiyati (2018) explored The Role of Classroom Teachers in Improving Student Learning Motivation, and lastly, Hendra (2017) studied The Role of Teachers in Improving Students' Learning Motivation in Sociology Subjects Class IX at SMA Laboratorium Malang.

Learning is currently carried out digitally. However, teachers faced difficulties because of adjustments to the new system. Based on the observations made by 
researchers, the following are the findings: (1) not all students can understand the material presented. (2) Students still feel different when studying directly at school and studying at home. (3) All students do not own the learning facilities, 4) Parents or adults. (5) Accompany not all students) some teachers have to learn from the beginning about the use of applications in learning. (6) The teacher's assignments piled up even though learning activities are carried out online.

The purpose of this study is to find out the implementation of digital-based thematic learning activities and the factors that facilitate and inhibit the application of digital-based thematic learning activities at SD (Elementary School) IT Nur Hidayah Surakarta.

\section{METHOD}

\section{Type and Design}

This type of research is qualitative research with a descriptive qualitative research approach. Qualitative research is an activity of collecting data on a phenomenon, social activity, perception, event, beliefs, attitude, and thoughts individually or in groups (Anggito \& Setiawan, 2018). The qualitative descriptive research designs were used to describe the existing phenomena, which are natural or done without any manipulation (Fitrah, 2017).

Research with a qualitative descriptive design does not manipulate or change the variables studied but provides an overview according to the actual conditions. This study has a characteristic that is found in understanding the process by describing everything related to the research carried out.

\section{Data and Data Sources}

The data used in this study were qualitative. The collected data were gathered through interview transcripts and documentation. In addition, it used primary and secondary data. Primary data is the leading data taken directly from the informant, who has the position and ability to provide information about the research (Elihami \& Syahid, 2018). The primary data sources were grade II and grade IV teachers who had taught at least two years in that class. The Secondary data were collected in documents, books, print media, and relevant previous research (Shahid, 2018). The secondary data obtained by researchers came from books that had a direct or indirect relationship with the title being studied and related to the subject matter of the research. In addition, they had relevance to the discussion to be studied.

The sources of data obtained in this study came from the two teachers from each class II and IV, who have taught in that class for at least two years to understand the class's state. Second, two students from classes II and IV were active and had good communication skills. Lastly, the principal of the school.

\section{Data collection technique}

\section{Interview}

Interviews are one of the data collection techniques carried out by giving questions directly to the parties concerned to obtain the necessary information. Interviews are a process to obtain information about research using question and answer between researchers and informants (Surayya, 2015). Interview activities in this study were carried out with the teacher, student, and principal informants as data sources. Researchers met directly with relevant informants while still complying with health protocols in collecting interview data. The researcher asked several questions to teachers, students, and school principals regarding several things related to the research. 


\section{Observation}

Observation is an activity carried out to obtain data naturally according to existing conditions without manipulation (Surayya, 2015). Observations in this study are nonparticipant observations, which means that researchers do not take full advantage of every activity carried out by the object. Several things were observed, namely learning activities, conditions and facilities used, the student learning conditions, and the role of teachers in digital-based thematic learning.

Observations were made to obtain data directly related to the research. The results of observations were used to determine the next research steps to take action according to the current situation in the field. The data from the observations were arranged systematically, and the data were obtained directly from the school.

\section{Data Validity}

The validation technique or the validity of the data used in this study are source triangulation and technical triangulation. According to Moleong (2013), triangulation is a technique of checking the validity of the data by utilizing something else outside the data for checking purposes or as a comparison against the data.

According to Sugiyono (2015), source triangulation allows the researchers to use the same data collection techniques from several different sources. On the other hand, technical triangulation is data collection with different techniques but with the same source. In this research, the researcher used both triangulations to compare the results of interviews between teachers and students regarding the role of teachers in digital-based thematic learning in schools. In contrast, the triangulation technique was used by researchers is to compare the data from interviews and observations with the documentation data obtained.

\section{Data analysis}

Based on the problem formulation and research objectives, the data analysis used in this research is an interactive model developed by Miles and Huberman (2007), which includes several stages, such as raw data collection, data reduction, data presentation, and concluding.

\section{RESULT}

Based on research conducted, the following are the data obtained by researchers.

\section{Digital-Based Thematic Learning Activities}

\section{Digital-Based Thematic Learning Planning}

"At the beginning of the pandemic, module learning activities were inserted into flash drives and WhatsApp. Then use the modules and form small study groups. Until now, only using modules and zoom meetings."(WK)

"Currently, learning activities use zoom meetings, if you have previously used WhatsApp, flash disks to take the material in the form of modules, form small study groups, and then do a thing through zoom. Before carrying out learning, we make 
RPP in advance which is adjusted to the learning activities that will be carried out" (EN)

"Learning activities use zoom meetings for now. Previously used flash, WhatsApp, small study groups, and modules. For the module until now still using. Before teaching, we have made lesson plans first to be used as guidelines when teaching." (WL)

Based on the study results, it was found out that the learning activities were guided by the lesson plans that were adjusted to the needs of the students when teaching. The concepts of learning activities were adjusted to the existing conditions so that students could still get good learning.

\section{Implementation of Digital-Based Thematic Learning}

"In January-May, the learning activities used modules and meetings via zoom. The learning activities carried out are starting from the opening, the core, and the closing." (WK)

"Currently, learning activities use zoom meetings. Learning activities are almost the same as when in class, namely opening, core, and closing activities, and continue to apply a scientific approach."(EN)

"Current learning activities use zoom meetings. Learning activities are made as close as possible to classroom learning. And apply $5 \mathrm{M}$ for students so that students still get meaningful learning." (WL)

"Learn online from zoom."(ND)

"Learning activities are carried out online from their homes via zoom."(LT)

Researchers concluded that even though learning activities were carried out digitally, teachers still provide meaningful learning for students.

\section{Evaluation of Digital-Based Thematic Learning}

"Every time after studying, students will be asked about the material that has been studied, whether they understand it and whether there are any questions."(EN)

"Every time after studying, students will be asked about the material that has been studied, whether they understand it and whether there are any questions." (WL)

The role of the teacher in the thematic learning activities is carried out on a digital basis. 
"Teachers have a crucial role in learning activities because teachers carry out learning with students. Although different, the teacher's role is also difficult in the current situation. In addition to teaching online, teachers also continue to have an important role in instilling character in students in the current situation." (WK)

"The teacher's role is vital, especially for the lower classes. In this second grade, the child needs the role of the teacher and also the parents very much."(EN)

"Teachers have an important role for students, especially for elementary school students. Because when at home students will still obey and trust what the teacher says rather than their parents." (WL)

\section{The Role of Teachers as Educators}

"We give priority to character building for second graders, such as religious, honest, and disciplined characters. Second graders are young and still need a lot of guidance and direction. The potential is not visible yet, so that I will do my best."(EN)

"I see the potential of students through zoom learning, and when asked to make or do something, the results of the students themselves will be seen. We always monitor the character that must exist in the child, such as being religious, honest, disciplined, and independent." (WL)

\section{Teacher's Role as a Teacher}

"The material given is in the form of a module that has been made previously. The modules given will be explained one by one by the teaching teacher."(EN)

"The material given is made into modules for each lesson. Each module will be explained one by one through zoom, which is held every Monday-Friday."(WL)

\section{Teacher's Role as Facilitator}

"Motivating students before and after learning activities. Provide any material that students will study. Besides, the teacher guides students during the learning process."(EN)

"To keep students motivated to continue learning, we motivate videos that can be watched by students in addition to using words of praise so that students gain pride and happiness. Also, we provide guidance always so that when students have difficulty learning or experience other difficulties in their daily lives, we are there to assist" (WL) 


\section{Teacher's Role as Service}

"Learning activities are made relaxed, so students do not feel tense. In the past, when students started using zoom, there was a tension that was visible from their expressions. However, as time goes on, they get used to it and greet each other via zoom."(EN)

"Making online learning activities is almost the same as learning in class. Learning does not only focus for hours on only studying, but there are activities that students are not sleepy such as stretching muscles, gymnastics, asking students to look for some shapes of objects, and other things to keep students moving. The school also provides facilities in the form of flash disks for students whose purchases come from BOS funds." (WL)

\section{Teacher's Role as Designer}

"Learning strategies and models are made as simple as possible. The important thing is to involve students and make it easier for students to learn."(EN)

"The learning strategies and models used cannot be as wide or varied when learning directly. Teachers also take advantage of the environment around students and the experiences of the students themselves. This can make students happy in learning because they are directly involved." (WL)

\section{Teacher's Role as Manager}

"Class administration activities are still the same as learning before the pandemic. Like doing attendance to students before learning begins, processing student values, making report cards for students and other things are still the same."(EN)

"Regarding class administration, it is still the same as when entering school, taking attendance one by one via zoom, making report cards for students, and completing several other administrations." (WL)

\section{Teacher's Role as Assessor}

"Our assessment activities for teachers to give leeway to students are also instructions from the principal. We do not force students' abilities, so students only learn according to their abilities. The scoring is based on the value of assignments, daily tests, PAS, and PAT."(EN) 
"Many things can generate value for students, such as assessing assignments, daily tests, working through google forms, PAS, and PAT. The teacher gives a value according to the development, activity, and timeliness in collecting assignments either in photos or videos. We also provide concessions for students and parents." (WL)

\section{Teacher's Role as an Example}

"Although learning activities are carried out digitally, the teacher remains a role model for students, even though we only meet through zoom meetings. So we still maintain good behavior, courtesy, and polite speech. The children are elementary to imitate the teacher."(EN)

"It is easy for children to imitate their teacher. Even though they learn through zoom meetings, they still imitate their respective class teachers. The teacher must always maintain attitudes, manners, speech, and behavior even though currently learning activities are online." (WL)

\section{The Teacher's Role as a Reformer}

"Teachers must be able to adapt to existing situations and conditions, as this is a new thing for us. At first, we found it very difficult to live with, but slowly we were able to adjust."(EN)

"We will continue to do new things in learning activities, considering the current situation and conditions that can change. We have never had a learning activity like this before because this is a new thing. Now we can live it smoothly and pleasantly." (WL)

Based on the results of interviews and observations, teachers continue to carry out their roles as they should. They take the roles of educator, teacher, facilitator, service, designer, manager, assessor, role model, and reformer. This is done to continue to provide the best for students.

Factors that encourage and inhibit the implementation of digital-based thematic learning activities.

\section{Driving Factor}

"Good cooperation from all school residents, supporting facilities, good support from the foundation and school committee, transfer of boss funds for student needs during online school. It also establishes good cooperation and communication with parents of students. An IT team forms 
each level to learn digitally together, thus saving time for learning."(WK)

"The schools provide wifi that all teachers can use. There is a different zoom link for each class, printed books from the National Education Office for learning activities, training for teachers in digital-based thematic learning activities. Good cooperation from parents, there are devices that students can use for digital learning, and there is a quota or wifi."(EN)

"The school's facilities are in the form of wifi that teachers can use. There is training on digital learning with fellow teachers who understand better. There is a zoom for each class in learning. There is a good response from parents to provide learning tools and quotas. There is assistance when children study online." (WL)

\section{Inhibiting Factors and solutions}

"Teachers who cannot use the school's wifi are allowed to teach from home with a note that they must still come to school after teaching. Teachers who have an old version of the laptop and do not support the use of zoom are switched to using a cellphone. Students who do not take Zoom can learn through modules taken to school or sent via telegram. The school also holds parenting for student guardians."(EN)

"Unstable signal when zooming in at school, teachers are allowed to zoom from home then after zooming comes to school. Teachers who have an old version of the laptop and do not support the use of zoom are switched to using a cellphone. Signal problems students who cannot follow the zoom will still get the same material in video modules and record learning activities. For children who find it difficult to collect assignments, the teacher will always remind them every day and provide a limit for collecting assignments so they do not pile up. In addition, the school also holds parenting for student guardians." (WL)

"Once, sometimes the zoom likes to go in and out because the signal is lost. The cleric's voice is also sometimes lost."(ND)

"Once, when I joined Zoom, the signal sometimes disappeared when I was not using wifi or when the lights went out when using wifi. Sometimes the cleric's voice also falters." (LF)

The driving and inhibiting factors in the implementation of learning were found. However, every problem that exists must have a solution or other alternative that can be used. Good communication between schools and parents must be maintained so that learning is as expected. 


\section{DISCUSSION}

\section{Digital-Based Thematic Learning Activities}

Learning activities are carried out differently than before. The learning activities take advantage of existing technological advances with terms that are often heard based on digital. As in the current situation, it is impossible to learn in schools. The government has shifted learning digitally. According to Syarifudin (2020), learning activities must continue to be carried out even though during a global pandemic disaster. The government then decided to social distance in the world of education. Solutions are provided through online learning via virtual using specific applications. Its implementation must still pay attention to the competencies being taught because learning involves pedagogical, psychological, and didactic aspects simultaneously.

Prior to implementing learning, the teacher has prepared a Learning Implementation Plan or Rencana Pelaksanaan Pembelajaran (RPP). This is done for teachers to facilitate the learning activities. In addition to lesson plans, learning activities also use teaching materials in modules, textbooks, and videos. The module provided contains the primary learning materials. Meanwhile, the books used are the Indonesian National Education and Jsit books used as a guide for teachers and students. This is the following (Permendikbud No. 71 of 2013). The teaching materials are in textbooks as student handbooks and teacher guides.

The implementation of learning is adjusted to the RPP that has been made, which contains an opening, content, and closing. Depdiknas (2004) expressed that learning activities can be carried out in four stages, namely, the apperception (opening) stage, the information delivery stage (the activities to be carried out), the student participation stage (core), and the closing stage (evaluation). Learning activities apply a scientific approach called 5M (Observing, Questioning, Trying, Reasoning, Communicating). The application of $5 \mathrm{M}$ made it easier for students to understand thematic learning materials with previous knowledge. Maryono (2017) stressed that integrated thematic learning is applied to create active learning and build knowledge in students based on the cognitive structure they already have.

After the thematic learning activities are completed, the teacher evaluates to determine the achievement and success of learning activities. Astiti(2017) said that evaluation is a systematic activity carried out to determine the success and efficiency of the activities provided. If problems are encountered during learning activities, they can be resolved, and solutions are given.

\section{The Role of Teachers in Digital-Based Thematic Learning Activities}

Teachers in learning activities have a significant role to implement the planned learning successful. Even in different circumstances, such as today, thematic learning activities in elementary schools continue to be carried out. Mursalin (2017) expressed that teachers are one of the most dominant determining factors in education because they play a role in learning activities that are the core of the education process.

The teacher's role as an educator is to provide character education for students besides understanding the potential possessed by students and directing students to develop it. Potential development is adjusted to the interests and talents of students without any coercion from the teacher. Sanjaya (2016) said that students have different talents, interests, and abilities, which develop at different times. Teachers must provide direction for students to find potential in themselves as provisions for the future and be able to develop their potential to the fullest. Sadirman (2011) opined that as educators, 
teachers develop personality, foster students' character, and instill good character in students to become good students.

As a teacher, it is his/her role to provide students with the knowledge, help students understand the material being studied, and provide new material according to student needs. Sadirman (2011) expressed that the teacher should provide knowledge to students, guidance to train skills, guidelines, design learning, implement learning, and assess learning activities.

The teacher's role as a facilitator is to motivate students during learning activities. They should provide material that students have not understood and guide students during learning activities. Sanjaya (2016) mentioned that motivating learning activities is very important. Teachers must be creative in generating student learning motivation, such as arousing student interest, clarifying the goals to be achieved, giving appropriate praise, creating a pleasant learning atmosphere, providing assessments, commenting on student work, creating healthy competition, and other things.

The role of the teacher as a service is that the teacher always provides a sense of comfort for students in learning activities. He/she should provide supporting facilities for smooth learning. Sadirman (2011) emphasized that the services provided by the teacher to students are in the form of a sense of comfort for students in learning activities and providing facilities to support learning activities such as teaching aids and learning resources. Sanjaya (2016) opined that teachers have a role to provide services that can facilitate students in learning activities and provide facilities such as learning media and mastery of the material by the teacher so that students can more easily understand the material.

The teacher's role as a designer is to develop a learning program following the curriculum used. He/she should make lesson plans that are used as guidelines during learning activities. Fauzi Mulyatna (2018) said that the preparation of the RPP carried out by the teacher in choosing the method must be adjusted to the material being studied, in order to create an inspiring, fun, efficient and interactive learning atmosphere.

The teacher's role as a manager is to complete class administration by making attendance, filling out report cards and registering student grades. He/she should create annual and semester programs. Sadirman (2011) said that as a class manager, the teacher carries out class administration such as a list of student grades, student attendance, filling out report cards and other things. In addition, teachers also have semester programs, annual programs and have teaching plans that have determined learning strategies and methods.

The teacher's role as an evaluator is to provide values according to the process, abilities, and results obtained by students without any value gaps. In addition to assessment, teachers also conduct evaluations, to determine the success of learning activities. Astiti (2017) mentioned that evaluation is a systematic activity carried out to determine the success and efficiency of the activities provided. This is in corroboration of Fadlilah (2018) who emphasized that the teacher is tasked with collecting data or information about student development in the learning process that has been passed.

The role of the teacher as an example is that the teacher always provides a good example in terms of behavior, speech, manners, and attitudes. Juwitawati (2019) highlighted that the activities carried out by the teacher will be imitated by the students because it is as if the teacher is a mirror for students while students play a role as a reflection of the teacher.

The teacher's role as a reformer is that the teacher can always adapt to the conditions that are happening in an environment. Learning activities can be adapted to the existing environment. Currently,learning activities are carried out digitally. Teachers must be able to adapt quickly. Juwitawati (2019) stressed that teachers are able to make adjustments to 
existing developments, constantly updating their learning activities and ways of thinking. It also creates creative learning activities, determines new methods, strategies, and concepts in learning activities.

Factors that encourage and inhibit the implementation of digital-based thematic learning activities.

The driving factor in the success of digital-based learning activities is the collaboration between the school and the student's guardian. The supporting facilities provided by schools for teachers can be used properly. Facilities for students provided by guardians are according to the student's learning needs. There is training conducted by the school for its teachers. Zoom meeting is available for each class. Diknas books and Jsit books for teachers and students. The flash for each student contained the learning module. The modules are available in attractive video and powerpoint formats. There is assistance provided by the guardian of students when students study.

The inhibiting factor is the wifi which is less stable in schools, so the solution was teachers teach from their respective homes and then go back to school. The device,which is a laptop, that is less supportive,the teacher teaches using a cellphone. Students' signals are not stable, so sometimes, they do not follow the zoom, students can continue to learn through modules and learning records. Not all students have cellphones so sometimes students do not follow zoom.

\section{CONCLUSION}

\section{Novelty and Contribution}

Learning activities are currently being carried out online by grade II and IV students at SD IT Nur Hidayah Surakarta. Teachers and students need to adapt to this situation in order to continue to carry out learning activities smoothly. Before the implementation of learning, the teacher first makes a lesson plan as a guide during the implementation of learning. In addition, he/she also provides education textbooks, Jsit textbooks, modules in ppt and video formats. Learning activities still apply the scientific approach (5M) to provide meaningful learning for students.

Teachers have an important role in the implementation of digital-based learning activities today because teachers interact directly with students through the Zoom Meeting application. Teachers always carry out their roles well and learning activities must be carried out differently. The existing teacher role are the following: the teacher's role as an educator, the teacher's role as a teacher, the teacher's role as a facilitator, the teacher's role as a service, the teacher's role as a designer, the teacher's role as manager, the teacher's role as an assessor, the teacher's role as an example,and the teacher's role as a reformer.

There are driving factors in the implementation of digital-based learning activities at SD IT Nur Hidayah Surakarta in grades II and IV are the existence of wifi in schools, training for teachers, Zoom meetings, flash drives for students, official package books and jsit books, modules in the form of videos and powerpoint. Moreover, there is cooperation between the parents and the school. Student guardians provide supporting facilities for students to learn in the form of devices and quotas or wifi. Students are provided assistance in learning activities.

There are inhibiting factors and solutions provided in the implementation of digitalbased learning activities at SD IT Nur Hidayah Surakarta in grades II and IV. Due to the limitations of wifi in schools, the solution provided by the teacher can be zoom meetings at their respective homes. Also, when the students have limited facilities, they are 
provided with the modules and videos of learning outcomes. When their signal or connection is weak, then the teacher will give permission not to take part in the zoom meeting, but still learn on their own through modules and videos of learning outcomes.

There are several research limitations in this study, namely; the limited time for interviews with students because students are still learning from their respective homes, and not all students' parents allow them to be interviewed. Researchers only participated in learning activities through zoom meetings after UTS, so they could not find out about learning activities before UTS.

Based on the results of the research, the suggestions made were that the principal should pay more attention to the availability of wifi facilities for teachers so that all can use the facility. The principal should have to schedule to follow the learning activities of each class, in order to better know the difficulties faced by each class. The teacher can divide the online class into two meetings if there are many students in the class so that all students get attention. Teachers should always pay attention to the development of each student during these online learning activities, so students can still develop themselves according to their potential. The researchers feel there are still many shortcomings. Therefore, future researchers are expected to be able to complete research on the role of teachers in digital-based thematic learning activities in elementary schools.

\section{REFERENCES}

Anggito, A., \& Setiawan, J. (2018). Metodologi Penelitian Kualitatif. In Jawa Barat: CV Jejak (pp. 7-8).

Arifudin, I. S. (2015). Peranan Guru Terhadap Pendidikan Karakter Siswa di Kelas V SDN 1 Siluman. PEDADIDAKTIKA: Jurnal IImiah Pendidikan Guru Sekolah Dasar, 2(2), 175186. https://ejournal.upi.edu/index.php/pedadidaktika/article/view/5844

Astiti, K. A. (2017). Evaluasi Pembelajaran. In Yogyakarta: CV Andi Offset (pp. 17-18).

Enriquez, M. A. S. (2014). Students ' Perceptions on the Effectiveness of the Use of Edmodo as a Supplementary Tool for Learning. DLSU Research Congress, 6-11. https://doi.org/10.1017/CBO9781107415324.004

Fadlilah, S. N. (2018). Peran Guru dalam Meningkatkan Motivasi Belajar Siswa pada Pembelajaran Tematik di Kelas IV SDI As-Salam Malang. Skripsi. Tidak Dipublikasi. Fakultas IImu Tarbiyah Dan Keguruan. Universitas Islam Negeri Maulana Malik Ibrahim Malang : Malang. http://etheses.uin-malang.ac.id/12905/1/14140130.pdf

Fauzi Mulyatna, Farah Indrawati, \& Leny Hartati. (2018). Pelatihan Pembuatan Rencana Pelaksanaan Pembelajaran Berdasarkan Kurikulum 2013 di Yayasan Raudlatul Jannah. Abdimas Dewantara, 1(1), 11-22. http://jurnal.ustjogja.ac.id/index.php/abdimasdewantara/article/view/2128

Fitrah, M. (2017). Metodologi Penelitian. In Jawa Barat: CV Jejak (pp. 35-37).

Hamid, A. (2017). Guru Professional. Guru Profesional, 17(November), 274-285. http://ejurnal.staialfalahbjb.ac.id/index.php/alfalahjikk/article/view/26

Hendra. (2017). Peran Guru dalam Meningkatkan Motivasi Belajar Siswa pada Mata Pelajaran Sosiologi Kelas XI di SMA Laboratorium Malang. Skripsi. Tidak Dipublikasi. Fakultas IImu Tarbiyah Dan Keguruan. Universitas Islam Negeri Maulana Malik Ibrahim Malang : Malang. http://etheses.uin-malang.ac.id/9264/

Iftakhar, S. (2016). Google Classroom: What Works and How? Journal of Education and Social Sciences, 3, 1-17. https://doi.org/10.1080/10494820.2020.1789672

Jordan, C. (2020). Coronavirus outbreak shining an even brighter light on internet disparities in rural America. The Hill. https://thehill.com/blogs/congressblog/technology/488848-coronavirus-outbreak-shining-an-even-brighter-light-on

Juwitawati, B. I. (2019). Peran Guru dalam Mengatasi Kesulitan Belajar Siswa pada Pembelajaran Tematik Kelas IV di SD Negeri Malangan 03. Skripsi Universitas 
Muhammadiyah Surakarta. http://eprints.ums.ac.id/77107/

Karp, P., \& McGowan, M. 2020. "Clear as mud" schools ask for online learning help as coronavirus policy confusion persists Australia news. The Guardian. https://www.theguardian.com/australia-news/2020/mar/24/clear-as-mud-schoolsask-for-online-learning-help-as-coronavirus-policy-confusion-persists

Kartika, S. D. (2016). Peran Guru dalam Memotivasi Belajar Siswa pada Mata Pelajaran IPS Terpadu di SMP PGRI 2 Ciledug. Skripsi. Tidak Dipublikasi. Fakultas IImu Tarbiyah dan Keguruan. Universitas Islam Negeri Syarif Hidayatullah: Jakarta.

Maryono, M. (2017). Peran Guru Dalam Menerapkan Pembelajaran Tematik di Sekolah Dasar. Jurnal Gentala Pendidikan Dasar, 2(1), 72-89. https://doi.org/10.22437/gentala.v2i1.6819

Miles, \& Huberman. (2007). Metode Evaluasi Kualitatif (pp. 45-49).

Moleong, L. J. 2013. Metodologi Penelitian Kualitatif. Bandung: Remaja Rosda Karya. Mursalin, Sulaiman, \& Nurmasyitah. (2017). Peran Guru dalam Pelaksanaan Manajemen Kelas di Gugus Bungong Seulangakecamatan Syiah Kualakota Banda Aceh. Jurnal Ilmiah Pendidikan Guru Sekolah Dasar, 2(1), 105-114. http://www.jim.unsyiah.ac.id/pgsd/article/view/2538

Rosyidah, I. (2019). Peran Guru Kelas dalam Menciptakan Suasana Pembelajaran yang Efektif dan Menyenangkan untuk Meningkatkan Motivasi Belajar Siswa. Skripsi. Tidak Dipublikasi. Fakultas IImu Tarbiyah Dan Keguruan. Universitas Islam Negeri Walisongo: Semarang, 1-70.

Permendikbud No. 71 Tahun 2013 tentang Buku Teks Pelajaran dan Buku Panduan Guru untuk Pendidikan Dasar dan Menengah.

Sadirman. (2011). Interaksi dan Motivasi Belajar Mengajar. Jakarta: Rajawali Press. hlm. 56-57.

Sanjaya, W. (2016). Strategi Pembelajaran Berorientasi Standar Bahan Ajar. In Jakarta: PT Elex Media Komputindo (pp. 12-14).

Sicat, A. S., \& Ed, M. A. (2015). Enhancing College Students 'Proficiency in Business Writing Via Schoology. 3(1), 159-178. https://www.ijern.com/journal/2015/January2015/14.pdf

So, S. (2016). Mobile instant messaging support for teaching and learning in higher education. Internet and Higher Education. https://doi.org/10.1016/j.iheduc.2016.06.001

Sugiyono. (2015). Memahami Penelitian Kualitatif. Bandung: Alfabeta.

Sumiyati. (2018). Peran Guru Kelas dalam Meningkatkan Motivasi Belajar Siswa. Jurnal Pendidikan Agama Islam Tarbawi, 3(2), 145-164.

Surayya, R. (2015). Pendekatan kualitatif dalam penelitian kesehatan. Jurnal Kedokteran Dan Kesehatan Malkusaleh, 75-84.

Elihami, and Syahid, A. (2018). Penerapan Pembelajaran Pendidikan Agama Islam dalam Membentuk Karakter Pribadi yang Islami. Edumaspul Jurnal Pendidikan, 2, 79-96. https://ummaspul.e-journal.id/maspuljr/article/view/17

Syarifudin, A. S. (2020). Impelementasi Pembelajaran Daring untuk Meningkatkan Mutu Pendidikan Sebagai Dampak Diterapkannya Social Distancing. Jurnal Pendidikan Bahasa Dan Sastra Indonesia Metalingua, 5(1), 31-34. https://doi.org/10.21107/metalingua.v5i1.7072

Undang-Undang Republik Indonesia Nomor 20 Tahun 2003 Tentang Sistem Pendidikan Nasional

UNESCO. (2020). Guidance on Open Educational Practices during School Closures : Utilizing OER under COVID-19 Pandemic in line with UNESCO OER Recommendation.

Utami, R. D., Laila, A., Rahmawati, F. P., Umam, S. Z., \& Argyansyah, R. (2012). Pendampingan Guru-guru SD Muhammadiyah Kecamatan Colomadu Karanganyar 
dalam Pembelajaran Berkarakter dan Menyenangkan. Jurnal Warta, 15(2), 108-113. Zulaiha, D. (2013). Peran Guru Sekolah Dasar Dalam Pembelajaran Di Era Teknologi Digital. Journal of Chemical Information and Modeling, 53(9), 1689-1699. https://jurnal.univpgri-

palembang.ac.id/index.php/Prosidingpps/article/download/1887/1681 